\title{
Inulinase from Rhodotorula mucilaginosa: immobilization and application in the production of fructooligosaccharides
}

\author{
Geise Camila de Araujo Ribeiro ${ }^{1}$ Pedro Fernandes ${ }^{2,3}$ - Dayse Alessandra Almeida Silva ${ }^{4}$. \\ Hugo Neves Brandão ${ }^{4} \cdot$ Sandra Aparecida de Assis ${ }^{1}$
}

Received: 31 March 2021/Revised: 15 May 2021/Accepted: 8 June 2021/Published online: 16 June 2021

(C) The Korean Society of Food Science and Technology 2021

\begin{abstract}
The crude extract containing inulinase from Rhodotorula mucilaginosa was obtained by submerged fermentation. Inulinase was immobilized on chicken eggshell by physical adsorption and covalent crosslinking, using glutaraldehyde as a crosslinking reagent, and Celite by adsorption. Fructooligosaccharides production was performed using immobilized inulinase $(5 \%, \mathrm{w} / \mathrm{v})$ and inulin substrate solution under experimental conditions evaluated through Doehlert experimental design. The production of inulinase was optimized for concentrations of D-glucose and yeast extract at 12.5 and $0.5 \mathrm{~g} / \mathrm{L}$, respectively, resulting in an optimal activity of $0.62 \mathrm{U}$. The optimal $\mathrm{pH}$ and temperature for enzyme activity were 8.0 and $75^{\circ} \mathrm{C}$, respectively, leading to an optimal activity of $3.54 \mathrm{U}$. The highest immobilization efficiency (46.27\%) was obtained upon immobilization on Celite. Immobilization by adsorption to eggshell allowed for specific activity of $4.15 \mathrm{U} / \mathrm{g}$, and adsorption to Celite resulted in specific activity of $3.70 \mathrm{U} / \mathrm{g}$. The highest titer in fructooligosaccharides was obtained with an initial inulin concentration
\end{abstract}

Sandra Aparecida de Assis

sandrinhaassis@yahoo.com.br; sandraassis@uefs.br

1 Laboratory of Enzymology and Fermentation Technology, Department of Health, State University of Feira de Santana, Av Transnordestina, Km 0, BR 116, Feira de Santana, Bahia 44036-900, Brazil

2 DREAMS and Faculty of Engineering, Lusófona University, Lisboa, Portugal

3 Department of Bioengineering, IBB - Institute for Bioengineering and Biosciences, Instituto Superior Técnico, University of Lisbon, Lisboa, Portugal

4 Laboratory of Vegetal Bioprospection, Department of Health, State University of Feira de Santana, Av Transnordestina, Km 0, BR 116, Feira de Santana, Bahia 44036-900, Brazil of $250 \mathrm{~g} / \mathrm{L}(25 \%, \mathrm{w} / \mathrm{v})$, and a reaction time of $16 \mathrm{~h}$. Hence, immobilized inulinase proved to be a promising catalyst for fructooligosaccharides production since the formulation is performed through a simple, low-cost, and large-scale applicable methodology.

Keywords Hydrolase - Immobilization · Inulin · Optimization · Yeast

\section{Introduction}

Inulinases are part of the glycoside hydrolase family (GH32) that catalyzes the hydrolysis of inulin, a polydisperse fructan composed of $\beta$-2,1-linked D-fructose molecules with a terminal glycosyl residue, and of inulin-type fructans. Inulinases can be used either to produce syrups with high fructose concentration or in the production of fructooligosaccharides (Awad et al., 2017; Rawat et al., 2017; Singh and Singh, 2019).

Fructooligosaccharides (FOS) occur in nature by the catalytic action of enzymes with transfructosylating activity, but in small amounts (Chi et al., 2011). They can be synthesized by extraction of plant materials containing FOS, enzymatic synthesis from sucrose and enzymatic hydrolysis of inulin, but the extraction process from natural sources is not efficient due to the low yield obtained (Sandoval-González et al., 2018). Enzymatic synthesis from sucrose uses enzymes with transfructosylation activity, such as $\beta$-fructosyltransferase and $\beta$-fructofuranosidase. However, this method is not feasible when compared to inulin hydrolysis by inulinases, because the presence of glucose can cause inhibition of fructosiyl transfer, decreasing the concentration of the final product, in addition to the high cost of enzymes for transfructosylation. 
Inulin hydrolysis produces linear oligomers structurally resulting in a product composed of a mixture of oligosaccharides, namely 1-kestose (GF2), nystose (GF3), and 1Ffructofuranosyl-nystose (GF4) (Sandoval-González et al., 2018).

Due to their beneficial physiological effects and performance as a prebiotic, FOS are increasingly included in infant formula and other functional food products. FOS can be used to thicken dairy products and to improve the wetness of bakery products, to decrease the freezing point of frozen desserts, provide crispness to low-fat biscuits, act as a binder in nutritional bars of granola, enrich the fiber content in foods, and replace sucrose in formulations of high-intensity sweeteners, such as aspartame, to mask their often-referred undesirable residual flavor (Awad et al., 2017)

The production of FOS can be increased by the application of immobilized enzymes. Enzyme immobilization has become a powerful tool, complementing other strategies used routinely to improve protein properties. Some methods used for immobilization are the (1) method of adsorption/carrier binding, using insoluble supports in water as polysaccharide derivatives, synthetic polymers and glass, and (2) crosslinking/covalent bonding method with bi or multifunctional reagents, such as glutaraldehyde. The adsorption of enzymes results from hydrophobic interactions and salt bonds where the support is bathed in enzyme to obtain physical adsorption or the enzyme is dried on electrode surfaces by adsorption by ion exchange. The covalent binding of enzymes to the supports occurs due to their side chain amino acids and degree of reactivity based on different functional groups. This type of immobilization results in a stronger link between enzyme and support and greater stability in the orientation of the protein, which can improve its specificity (Datta et al., 2013; Holyavka et al. 2018).

However, when the food industry is considered, where often large amounts of cost-sensitive goods are to be produced, a low-cost immobilized enzyme formulation is mandatory to ensure the economic sustainability of the process (Basso and Serban, 2019). Eggshell is a natural biopolymer that can be obtained at a low cost that can be used as a carrier for enzyme immobilization (Salleh et al., 2016; Jiang et al., 2017). Celite, in turn, is a carrier composed mainly of $\mathrm{SiO}_{2}$, it is highly porous, and it has been used for the immobilization of enzymes since it has a low cost, low polarity, a large area of adhesion (Datta et al., 2013).

This work aimed to produce and characterize inulinase from $R$. mucilaginosa (CCMB 604) isolated from the Caatinga and its concomitant immobilization on solid carriers (eggshell and Celite) towards an enzyme formulation that can be effectively used for the production of fructooligosaccharide from inulin.

\section{Materials and methods}

\section{Microorganisms}

Samples of $R$. mucilaginosa (CCMB 604) were obtained from the Culture Collection of Microorganisms of Bahia (CCMB) of State University of Feira de Santana, Brazil. The yeast was maintained in YM agar at pH 6.2 (Lima et al., 2009). The culture medium was sterilized in a vertical autoclave (at $121{ }^{\circ} \mathrm{C} ; 15 \mathrm{~min}$ ). The microorganism was grown in YM agar at $28{ }^{\circ} \mathrm{C}$ for $48 \mathrm{~h}$ (IGO 150 Cell Life - Jouan, Waltham, United States of America).

\section{Fermentation}

Yeast cells grown in YM agar were resuspended in sterile saline solution to prepare the inoculum. The inoculum $\left(10^{8}\right.$ colony-forming units $/ \mathrm{mL}$ ) was added to Erlenmeyer flasks containing mineral medium $(0.1 \mathrm{~g}$ yeast extract, $1.0 \mathrm{~g}$ D-glucose, $0.3 \mathrm{~g}\left(\mathrm{NH}_{4}\right)_{2} \mathrm{SO}_{4}, 0.45 \mathrm{~g} \mathrm{KH}_{2} \mathrm{PO}_{4}, 0.025 \mathrm{~g}$ $\mathrm{MgSO}_{4}$, and $0.025 \mathrm{~g} \mathrm{CaCl}_{2}$ in $100 \mathrm{~mL} \mathrm{H}_{2} \mathrm{O}$ ) at $\mathrm{pH} 5.0$ (Patching and Rose, 1970). Fermentation was carried out in an orbital shaker (Tecnal ${ }^{\circledR}$ TE-424, Piracicaba, São Paulo, Brazil), at $100 \mathrm{rpm}$ and $28^{\circ} \mathrm{C}$ for $48 \mathrm{~h}$. After fermentation, the medium was centrifuged at $24,000 \times g$ for $10 \mathrm{~min}$ at $4{ }^{\circ} \mathrm{C}$ (Centrifuge 5804R-Eppendorf, São Paulo, São Paulo, Brazil), and the enzyme-rich supernatant was recovered, and stored at $4{ }^{\circ} \mathrm{C}$ in $0.05 \mathrm{M}$ acetate buffer pH 5.5 until further use.

\section{Enzyme assays}

Inulinase activity was determined by quantifying the amount of reducing sugars released from inulin. Thus, 100 $\mu \mathrm{L}$ enzyme extract solution was added to $900 \mu \mathrm{L}$ of $20 \mathrm{~g} / \mathrm{L}$ inulin (Inulin from chicory-Sigma Aldrich ${ }^{\circledR}$, San Luis, Missouri, United States of America) solution in $0.05 \mathrm{M}$ acetate buffer $\mathrm{pH}$ 5.5. The reaction mixture was incubated at $50{ }^{\circ} \mathrm{C}$ for $15 \mathrm{~min}$. Reducing sugars were determined according to Miller (1959). Absorbance was determined at $540 \mathrm{~nm}$ with a UV/VIS spectrophotometer (Cary 50 UVVisible spectrophotometer, Varian Inc., São Paulo, São Paulo, Brazil). One inulinase activity unit (U) was defined as the amount of enzyme that catalyzed the production of $1 \mu \mathrm{mol}$ fructose per minute. All experiments were performed in triplicate.

Total protein $(\mathrm{mg})$ was determined according to the method described by Bradford (1976). The specific activity $(\mathrm{U} / \mathrm{mg})$ was determined as the ratio of inulinase activity 
(U) to total protein $(\mathrm{mg})$ concentration. All experiments were performed in triplicate.

\section{Optimization of inulinase production}

The optimization of the medium composition for the production of inulinase, quantified through inulinase activity, was carried out using Doehlert experimental design for two variables. Thus, the concentration of D-glucose and yeast extract in the fermentation medium was varied at five levels (5 to $15 \mathrm{~g} / \mathrm{L}$, central point $10 \mathrm{~g} / \mathrm{L}$ ) and three levels $(0.5$ to $1.5 \mathrm{~g} / \mathrm{L}$, central point $1.0 \mathrm{~g} / \mathrm{L})$, respectively. All assays were performed in triplicate. The experimental data processing and analysis of variance (ANOVA) to evaluate the lack of fit of the model to the experimental data were performed using STATISTICA software, version 7.0.

\section{Optimum pH and temperature for inulinase activity}

The effect of $\mathrm{pH}$ and temperature was carried out using the Doehlert experimental design. Thus, $\mathrm{pH}$ and temperature were varied at five levels (5.0 to 9.0, central point 7.0) and three levels $\left(30^{\circ} \mathrm{C}\right.$ to $70{ }^{\circ} \mathrm{C}$, central point $\left.50{ }^{\circ} \mathrm{C}\right)$, respectively. All assays were performed in triplicate. Experimental data processing and analysis of variance (ANOVA) to evaluate the lack of fit of the model to the experimental data were performed using STATISTICA software, version 7.0.

\section{Immobilization of inulinase using solid supports}

\section{Immobilization using eggshell as carrier}

Small pieces of chicken eggshells were immersed in boiling water for $30 \mathrm{~min}$. After settling, eggshells were washed five times with acetone and dried in an oven at $55.5^{\circ} \mathrm{C}$. The dry material was crushed mesh size $100(\approx 149 \mu \mathrm{m})$, according to Chatterjee et al. (1990) and Nighojkar et al. (1995).

Inulinase immobilization by absorption to eggshell was performed by adding $2 \mathrm{~mL}$ of crude enzyme extract to $0.5 \mathrm{~g}$ of crushed eggshell. The suspension was incubated at $12^{\circ} \mathrm{C}$ for $12 \mathrm{~h}$ with occasional agitation (Chatterjee et al., 1990; Nighojkar et al., 1995).

For inulinase immobilization by covalent crosslinking to eggshell, the enzyme was firstly adsorbed to crushed eggshell, as described previously, but with agitation for $2 \mathrm{~h}$. Glutaraldehyde $(25 \%, v / v)$ was added slowly while stirring with a glass rod until a final concentration of $1.2 \%(\mathrm{v} / \mathrm{v})$ was reached. The suspension was incubated under shaking (80 rpm) in an orbital shaker (Tecnal ${ }^{\circledR}$ TE-424, Piracicaba, São Paulo, Brazil) at $12{ }^{\circ} \mathrm{C}$ for $10 \mathrm{~h}$.
For both adsorption and covalent enzyme immobilization, enzyme loaded carriers were allowed to settle. The supernatants were stored at $4{ }^{\circ} \mathrm{C}$ for further characterization, while the immobilized enzyme derivatives were washed with $0.05 \mathrm{M}$ sodium acetate buffer $\mathrm{pH} 5.5$ for removal of waste before being used for inulin hydrolysis. All experiments were performed in triplicate.

\section{Immobilization using Celite as carrier}

Inulinase was immobilized through adsorption to Celite 545. Thus, $2.0 \mathrm{~mL}$ inulinase (crude enzyme extract) was added to $0.5 \mathrm{~g}$ of Celite, and the suspension was incubated under shaking $(80 \mathrm{rpm})$ in an orbital shaker (Tecnal ${ }^{\circledR}$ TE424, Piracicaba, São Paulo, Brazil) for $2 \mathrm{~h}$ at $28^{\circ} \mathrm{C}$. Two milliliters of either $0.05 \mathrm{M}$ sodium acetate buffer $\mathrm{pH} 5.5$ or acetone were then added, and the whole suspension was further incubated for $30 \mathrm{~min}$ at $28{ }^{\circ} \mathrm{C}$ (Castro et al., 1999).

In either case, enzyme loaded carriers were allowed to settle. The supernatants were stored at $4{ }^{\circ} \mathrm{C}$ for further characterization, while the immobilized enzyme derivatives were washed with $0.05 \mathrm{M}$ sodium acetate buffer $\mathrm{pH}$ 5.5 for removal of waste before being used for inulin hydrolysis. All experiments were performed in triplicate.

\section{Immobilized enzyme activity}

Immobilized inulinase activity was carried out, as described in Section "Enzyme assays". Thus, $20 \mathrm{~g} / \mathrm{L}$ inulin solution in $0.05 \mathrm{M}$ acetate buffer $\mathrm{pH} 5.5$ was added to the immobilized enzyme formulation and incubated at $50{ }^{\circ} \mathrm{C}$ for $15 \mathrm{~min}$ while shaking $(80 \mathrm{rpm})$ in an orbital shaker (Tecnal ${ }^{\circledR}$ TE-424, Piracicaba, São Paulo, Brazil). The specific activity of the immobilized enzyme was determined based on the amount of support (Eq. 1). Protein immobilization yield (\%) and immobilization efficiency $(\%)$ were determined according to Eq. 2 and 3, respectively.

Specific activity $=\frac{\text { Inulinase activity }(\mathrm{U})}{\text { Amount of } \sup \text { port used }(\mathrm{g})}$

$$
\begin{aligned}
& \text { Protein Immobilization yield }(\%) \\
& =\frac{\text { Total protein added }(\mathrm{mg})-\text { Protein in the supernatant }(\mathrm{mg})}{\text { Total protein added }(\mathrm{mg})} \\
& \quad \times 100
\end{aligned}
$$

Immobilization Efficiency (\%)

$$
=\frac{\text { Enzyme activity added-Activity of supernatant }}{\text { Enzyme activity added }}
$$




\section{Production of fructooligosaccharides}

Fructooligosaccharide (FOS) production was carried out in test tubes, each containing $2.5 \mathrm{~mL}$ of $200 \mathrm{~g} / \mathrm{L}$ inulin solution in $0.05 \mathrm{M}$ acetate buffer pH 5.5 unless stated otherwise, and $50 \mathrm{~g} / \mathrm{L}$ amounts of immobilized enzyme were incubated at $50^{\circ} \mathrm{C}$ under orbital shaking at $80 \mathrm{rpm}$ (Tecnal ${ }^{\circledR}$ TE-424, Piracicaba, São Paulo, Brazil) according to Silva et al. (2013). Reaction runs were performed under different conditions according to the Doehlert Matrix for two variables. Thus, the inulin concentration and duration of the reaction were varied at five levels $(50 \mathrm{~g} / \mathrm{L}$ to $250 \mathrm{~g} /$ $\mathrm{L}$, central point $150 \mathrm{~g} / \mathrm{L}$ ) and three levels $(8 \mathrm{~h}$ to $24 \mathrm{~h}$, central point $16 \mathrm{~h}$ ), respectively. All runs were performed in triplicate. Once the reaction stopped, the supernatants were collected and filtered through $0.22 \mu \mathrm{m}$ membranes. The reaction products were quantified by high-performance liquid chromatography (HPLC).

HPLC was performed with a Varian HPLC chromatography (Agilent, Santa Clara, California, United States of America), containing a Varian Polaris pump, using a refractive index detector, a reverse-phase column LiChrospher ${ }^{\circledR} \quad 100 \quad \mathrm{NH}_{2}$ spherically shaped particle $\left(10 \mu \mathrm{m}\right.$, pore $10 \mathrm{~nm}$, and surface area $\left.350 \mathrm{~m}^{2} / \mathrm{g}\right), 20 \mu \mathrm{L}$ volume of injection, a mobile phase of acetonitrile/ammonia hydroxide $0.04 \%$ (70:30) with $1.25 \mathrm{~mL} / \mathrm{min}$ flow rate, and temperature of both the detector and the column of $35^{\circ} \mathrm{C}$ (Nguyen et al., 1999; Silva et al., 2013; Kuhn et al., 2013). The reaction products were identified and quantified using a calibration curve of authentic standards of fructose, 1-kestose, and nystose (Sigma-Aldrich ${ }^{\circledR}$, San Luis, Missouri, United States of America). The results were compared by analysis of variance (ANOVA), and averages were compared by the F-test using STATISTICA, version 7.0.

\section{Results and discussion}

\section{Optimization of inulinase production}

Doehlert planning was used to optimize inulinase production by $R$. mucilaginosa (CCMB 604). The response surface plot and the contour plot are given in Fig. 1A, B, respectively. The response surface plot illustrates the effect of D-glucose and yeast extract concentrations in the production of inulinase, suggesting that enzyme production is favored as D-glucose to yeast extract concentration ratio increases. The contour plot established that, within the range of substrate concentrations selected, the production of inulinase is optimized for concentrations of D-glucose and yeast extract at 12.5 and $0.5 \mathrm{~g} / \mathrm{L}$, respectively, showing optimal activity of $0.62 \mathrm{U}$. The Pareto plot (Fig. 1C) shows
Fitted Surface; Variable: Activity (U)

2 factors, 1 Blocks, 9 Runs, MS Pure Error $=0.000049$
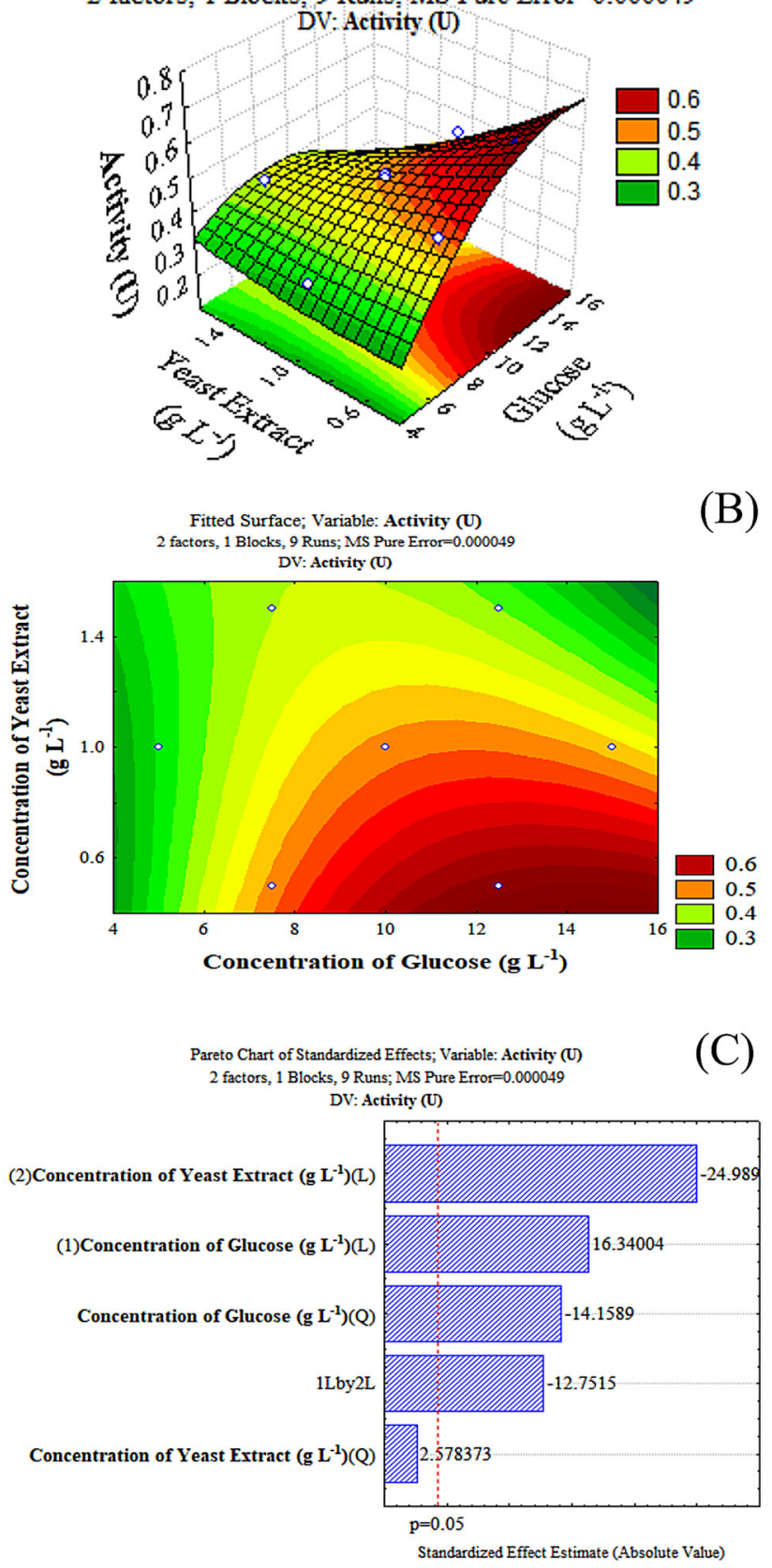

Fig. 1 A Response surface plot for the optimization of inulinase production by $R$. mucilaginosa (CCMB 604) as a function of glucose and yeast extraction concentrations in the fermentation medium; B Contour plot for the optimization of inulinase production by $R$. mucilaginosa (CCMB 604) as a function of glucose and yeast extraction concentrations in the fermentation medium; C Pareto plot for the optimization of inulinase production by $R$. mucilaginosa (CCMB 604) as a function of glucose and yeast extraction concentrations in the fermentation medium. (L) and $(\mathrm{Q})$ relate to linear and quadratic functions, respectively

that D-glucose and yeast extract concentrations are linearly (and the former quadratically) significant for the 
production of inulinase by $R$. mucilaginosa (CCMB 604), as well as the linear interaction of those two variables, all of these at 5\% significance level. A regression model representing the relationship between D-glucose and yeast extract concentrations and inulinase production indicated that the model was accurate and that there were no significant differences between predicted and experimental values.

A regression model representative of the relationship between glucose and yeast extract concentrations and inulinase production, expressed as inulinase activity (U), was developed (Eq. 4), where A is the response value (inulinase activity in $\mathrm{U}$ ), $\mathrm{CG}$, and $\mathrm{CY}$ are the $\mathrm{g} / \mathrm{L}$ concentrations of D-glucose and yeast extract, respectively.

$$
\begin{aligned}
\mathrm{A}= & -0.14158+0.12134 \times(\mathrm{CG})-0.00362 \\
& \times(\mathrm{CG})^{2}+0.08329 \times(\mathrm{YE})+0.04945 \\
& \times(\mathrm{YE})^{2}-0.03572 \times(\mathrm{CG})(\mathrm{YE})
\end{aligned}
$$

The regression model provided a good fit to the experimental data, as an $\mathrm{R}^{2}$ of 0.97 was obtained. Moreover, the ANOVA of the regression model performed, according to the Fisher distribution (F-test), showed that the F calculated (19.12) exceeded the F tabulated (9.01) at a 5\% significance level.

\section{Optimum pH and temperature for enzyme activity}

The response surface plot was generated that illustrates the influence of $\mathrm{pH}$ and temperature on inulinase activity for inulin hydrolysis (Fig. 2A). The contour plot (Fig. 2B) showed that inulinase activity peaked at $\mathrm{pH} 8.0$ and temperature of $75{ }^{\circ} \mathrm{C}$, showing optimal activity of $3.54 \mathrm{U}$. A regression model representing the relationship between $\mathrm{pH}$ and temperature and inulinase activity (U) can thus be considered accurate, and there were no significant differences between predicted and experimental values.

The Pareto plot (Fig. 2C) shows that both $\mathrm{pH}$ and temperature are linearly and quadratically significant for inulinase activity, as it is the linear interaction of those two variables, all at a 5\% significance level.

Nascimento et al. (2014) optimized the inulinase characterization produced by Pseudozyma sp. (CCMB 300) using Doehlert experimental design, with a response surface methodology, obtaining an optimum $\mathrm{pH}$ of 8.28 and optimum temperature of $54{ }^{\circ} \mathrm{C}$. In the optimization of Fungal endophyte (CCMB 328), Nascimento et al. (2012) obtained optimal enzyme activity conditions at a $\mathrm{pH}$ of 7.11 and a temperature of $48{ }^{\circ} \mathrm{C}$. The ability of fungi and yeasts to tolerate temperatures in extreme and nutrient-poor environments as in the Brazilian semiarid region indicates that there are species with adaptive mechanisms that can handle considerable stress, and the enzymes produced by
Fitted Surface; Variable: Activity (U)

2 factors, 1 Blocks, 9 Runs; MS Pure Error $=0.0001977$

(A)
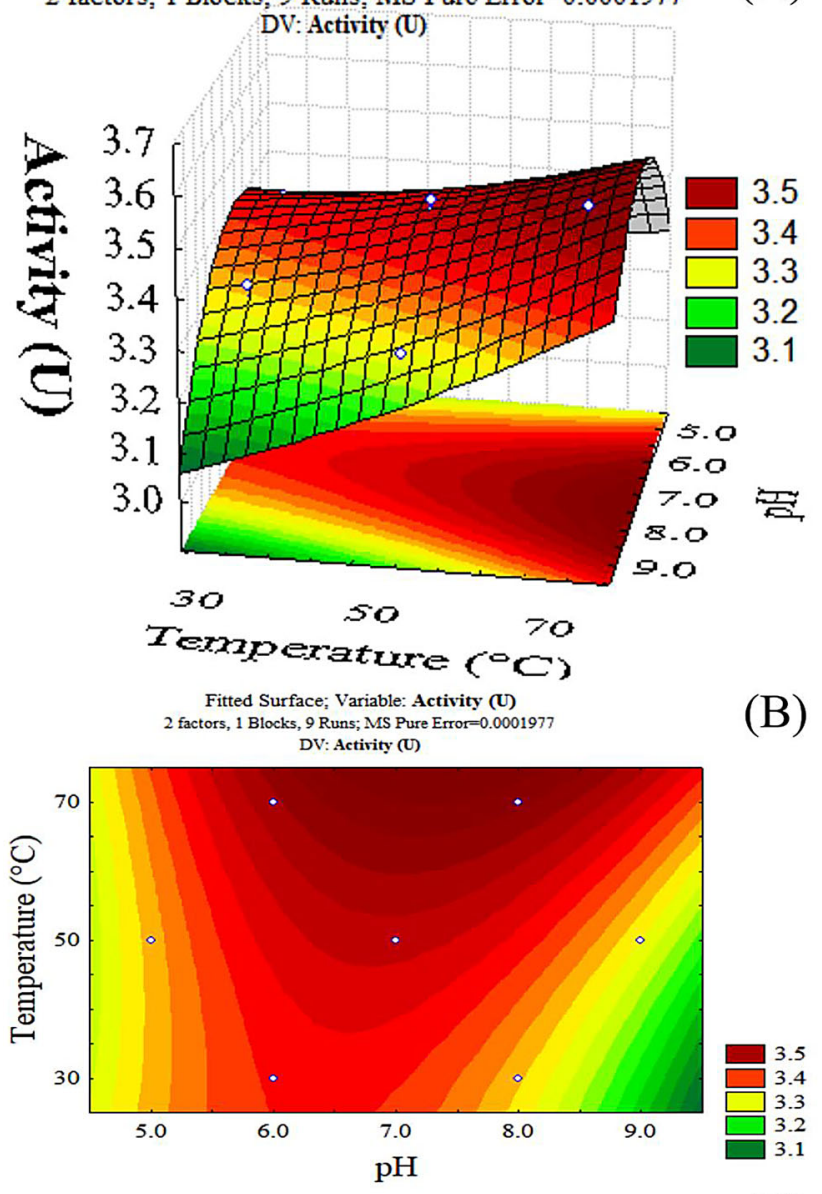

Pareto Chart of Standardized Effects; Variable: Activity (U) 2 factors, 1 Blocks, 9 Runs; MS Pure Error $=0.0001977$ DV: Activity (U)

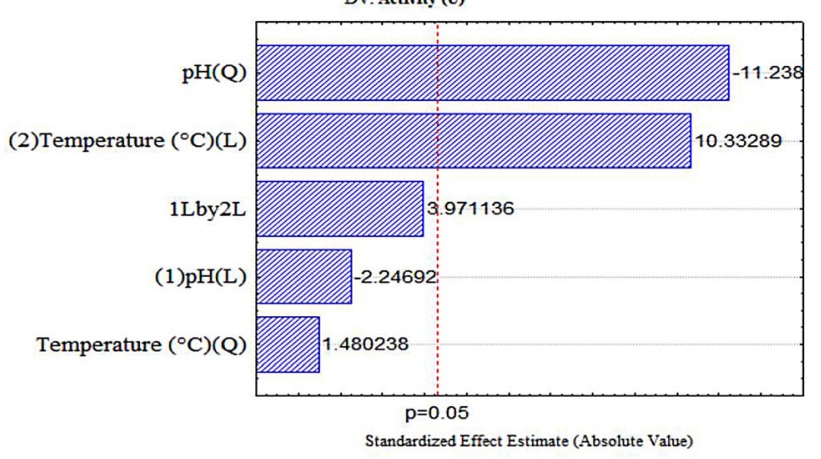

Fig. 2 A Response surface plot for the determination of the optimum $\mathrm{pH}$ and temperature for inulinase activity; B Contour plot for the determination of the optimum $\mathrm{pH}$ and temperature for inulinase activity; C) Pareto plot for the determination of the optimum $\mathrm{pH}$ and temperature for inulinase activity. (L) and (Q) relate to linear and quadratic functions, respectively

these fungi are of great interest for industrial application since they are expected to have greater stability and resistance to variations in temperature and $\mathrm{pH}$, besides the 
possibility of obtaining them through simpler culture media (Oliveira et al., 2013).

A regression model representative of the relationship between $\mathrm{pH}$ and temperature and inulinase activity (U) was developed (Eq. 5), where $\mathrm{A}$ is the response value (inulinase activity in $\mathrm{U})$, and $\mathrm{P}$ and $\mathrm{T}$ are $\mathrm{pH}$ and temperature $\left({ }^{\circ} \mathrm{C}\right)$ of the reaction medium, respectively.

$$
\begin{aligned}
\mathrm{A}= & 3.36650+0.25465 \times(\mathrm{P})-0.02686 \\
& \times(\mathrm{P})^{2}-0.03441 \times(\mathrm{T})+0.00024 \times(\mathrm{T})^{2}+0.00187 \\
& \times(\mathrm{P})(\mathrm{T})
\end{aligned}
$$

The regression model provided a good fit to the experimental data, as an $\mathrm{R}^{2}$ of 0.97 was obtained. Additionally, the analysis of variance (ANOVA) of the regression model showed that the $\mathrm{F}$ calculated (25.45) exceeded the $\mathrm{F}$ tabulated (9.01) at a 5\% significance level.

\section{Immobilization of inulinase using solid supports}

Inulinase immobilization experiments were performed using crude extracts displaying an average inulinase was activity of $2.69 \pm 0.09 \mathrm{U}$ (Table 1 ). The activity of these extracts from $R$. mucilaginosa fell roughly within the range reported for the production of inulinase by other fungi, either yeasts or molds.

Thus, Jain et al. (2012) reported $1.51 \mathrm{U}$ activity for inulinase from Kluyveromyces marxianus. This is further highlighted in a more recent paper by Rawat et al. (2015) comparing the volume activity of inulinases produced by several fungi, namely those from Penicillium citrinum (1.19 $\mathrm{U} / \mathrm{mL}$ ), Kluyveromyces marxianus (1.49 U/mL), Arthrinium pucciniodes (2.27 U/mL), Penicillium sp. (3.89 U/mL), Aspergillus ficuum (5.27 U/mL), Aspergillus sp. GNCC 2531 (5.63 U/mL), A. awamori (8.21 U/mL), and A. niger $(12.2$ $\mathrm{U} / \mathrm{mL})$. Overall, and although the activity of the two later strains exceeds by 3 - to 4.5-fold that of the extract from $R$. $m u c i l a g i n o s a$, the data produced is encouraging and suggests that this yeast can be considered a sound source for inulinases.

Inulinase activity of both the immobilized formulations of inulinase and the corresponding supernatants are depicted in Table 1. There was a lower activity for the immobilized derivative than for free enzyme (1.66 $\mathrm{U}$ and $2.69 \mathrm{U}$, respectively). Immobilization by adsorption to eggshell allowed for the highest specific activity $(4.15 \mathrm{U} / \mathrm{g})$ among the different immobilization methods tested (Table 1). On the other hand, the amount of protein and activity retained in the carrier was the lowest of all methods. With the further addition of glutaraldehyde, the specific activity of the formulation decreased by 1.7 -fold, yet almost all the protein was bound to the carrier, and activity recovery increased by 3.1 -fold.

Despite the innumerable advantages presented by the immobilization of biocatalysts, the interaction between enzyme and support can result in less enzymatic activity, due to the diffusion limitations of the support as well as the connection/interaction of the support with the substrate. A decrease in activity can also be caused by a failed failure in the immobilization process, by an inactivation of the enzyme due to the experimental conditions of the immobilization, or by an enzymatic inactivation due to enzymesupport interactions (Boudrant et al., 2019).

Moreover, inulinase production can be improved by using suitable strategies, such as medium engineering, among others. Ribeiro et al. (2018) studied the immobilization of inulinase produced by Pseudozyma sp., also from the Bahian semiarid region, obtaining $1.18 \mathrm{U}$ for immobilized derivative using eggshell by adsorption and $0.96 \mathrm{U}$ for derivative using eggshell by covalent crosslinking, thus indicating that $R$. mucilaginosa has a higher enzymatic activity.

Glutaraldehyde, a bifunctional compound, promoted crosslinking between enzyme molecules through the formation of covalent bonds between enzyme residues, and eventually covalent bonds between enzyme residues and the active groups in the carrier surface. Overall, this prevented enzyme leakage from the carrier and restricted enzyme mobility, contributing to its stabilization. Adsorption, although a mild method of enzyme immobilization, is often hampered by poor interaction between the carrier and the enzyme since only weak binding forces are involved (e.g., hydrophobic and van der Waals interaction). On the other hand, covalent binding may randomly inactivate enzyme molecules by compromising some residues of the active site or leading to its distortion, among other draw-

\begin{tabular}{|c|c|c|c|c|}
\hline Immobilized inulinase & $\begin{array}{l}\text { Immobilized activity } \\
\text { (U) }\end{array}$ & $\begin{array}{l}\text { Specific activity } \\
(\mathrm{U} / \mathrm{g})\end{array}$ & $\begin{array}{l}\text { Immobilization } \\
\text { efficiency }(\%)\end{array}$ & $\begin{array}{l}\text { Protein immobilization } \\
\text { yield }(\%)\end{array}$ \\
\hline Eggshell adsorbed inulinase & $1.66 \pm 0.02$ & 4.15 & 5.95 & 16.7 \\
\hline Eggshell crosslinked inulinase & $0.97 \pm 0.04$ & 2.49 & 18.22 & 100 \\
\hline $\begin{array}{l}\text { Celite adsorbed inulinase (full aqueous } \\
\text { medium) }\end{array}$ & $0.74 \pm 0.04$ & 1.47 & 46.47 & 66.7 \\
\hline Celite adsorbed inulinase (acetone) & $1.81 \pm 0.06$ & 3.70 & 28.25 & 58.3 \\
\hline
\end{tabular}
backs (Dalla-Vecchia et al., 2004).

Table 1 Enzymatic activity inulinase and standard deviations 
Fig. 3 Chromatograms of standards of A fructose, B 1kestose, and $\mathbf{C}$ ) nystose

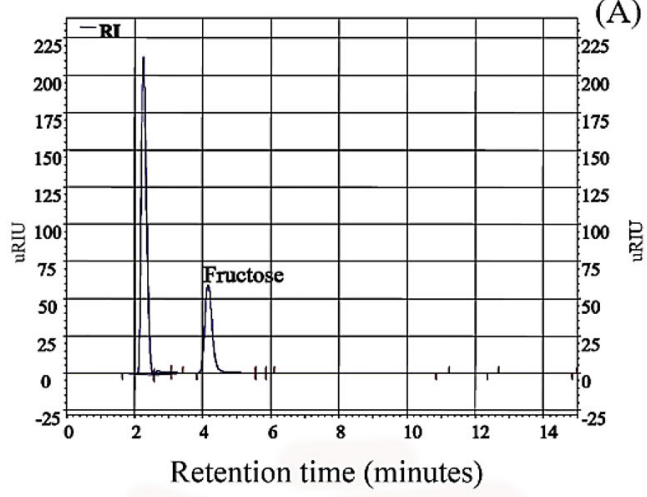

(A)

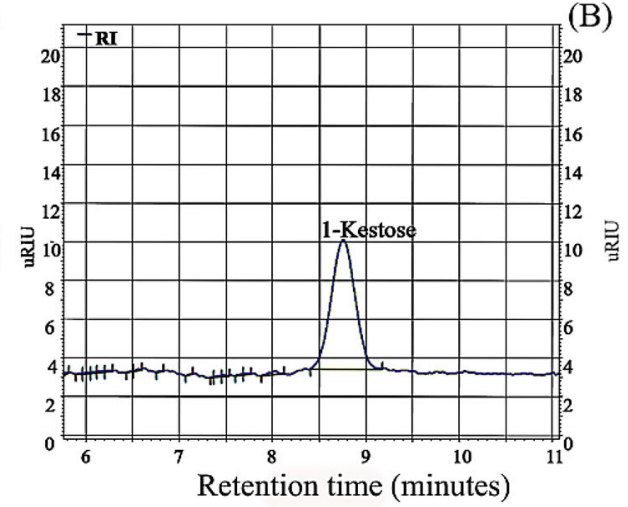

(C)

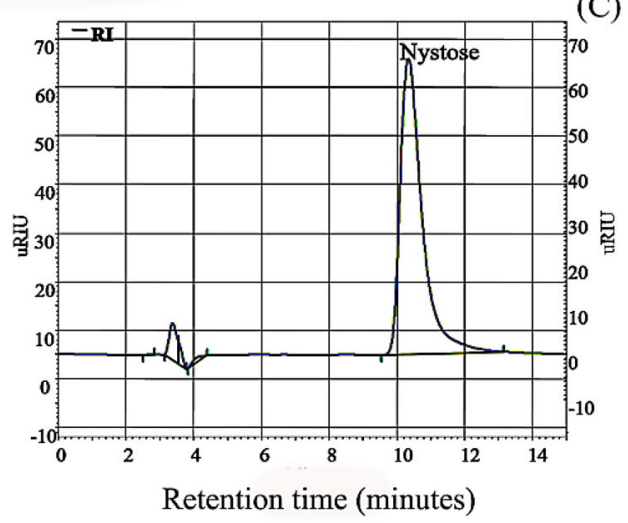

Still, immobilization onto eggshell by crosslinking is similar to other approaches. Trytek et al. (2015) studied the immobilization of inulinase using polymers containing epoxy groups and reported a maximum immobilization efficiency of $19.73 \%$. When using the commercial polymer Eupergit ${ }^{\circledR} \mathrm{C}$, the same authors reported an immobilization efficiency of $18.94 \%$. Thus, the use of eggshell as carrier for inulinase immobilization has some potential, since a similar immobilization efficiency $(18.21 \%)$ was obtained when compared with commercial carriers, namely Eupergit ${ }^{\circledR} \mathrm{C}$, while the cost of eggshell is lower and the immobilization procedure is simpler.

Adsorption of inulinase to Celite, namely when performed in the presence of acetone, resulted in relatively high specific activity $(3.70 \mathrm{U} / \mathrm{g})$ and overall higher protein and activity retention than to eggshell. Although for the latter two, full aqueous medium proved better than the use of acetone (Table 1). On the one hand, these results can be due to a more favorable non-specific interaction between the enzyme and carrier under the operational conditions used when Celite is matched to eggshell.

The relatively high specific activity when the enzyme was immobilized in the presence of acetone could probably be due to the load of ionizable groups of the enzyme in acetone, increasing the coupling with the support. This coupling increases the molecule's rigidity, preventing changes in the active site that may affect its binding to the substrate. Another important factor was the partition, since the support can affect the partition of the substrate and the products in the reaction mixture. The non-polar nature of Celite could result in an unfavorable partition of hydrophilic molecules. On the other hand, the addition of a hydrophobic solvent may lead to a decrease in aggregation, favoring the catalytic activity of inulinase (Pace et al., 2010).

Overall, the loss of enzyme activity upon immobilization observed, irrespectively of the immobilization method used in this work, can also be ascribed to secondary structural changes, leading to the loss of $\alpha$-helical structures and the gain of $\beta$-sheet structures, as reported previously when immobilization onto solid carriers was addressed (Holyavka et al., 2018).

\section{Production of fructooligosaccharides (FOS)}

The determination of FOS production was performed by the hydrolysis of inulin using both free (soluble crude extract) and immobilized inulinase. The products were identified by high-performance liquid chromatography (HPLC), using authentic standards of fructose (Fig. 3A), 1-kestose (Fig. 3B), and nystose (Fig. 3C). 


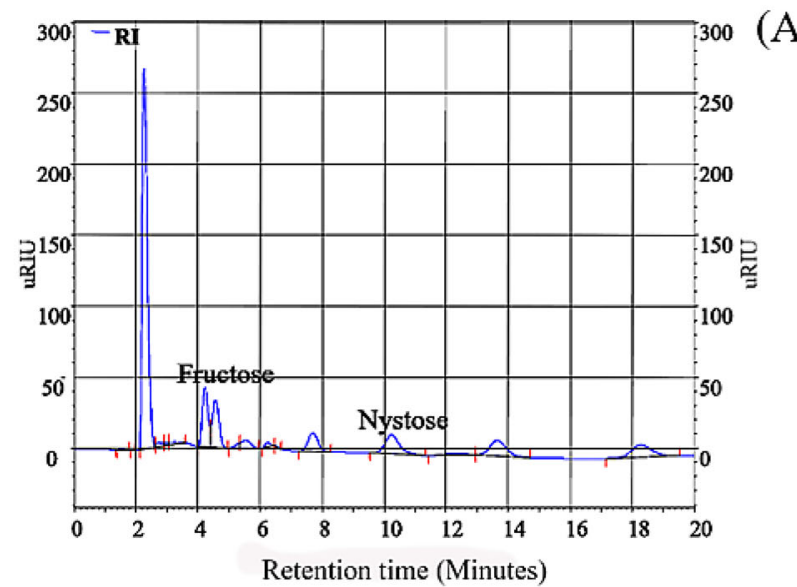

(A)

(B)
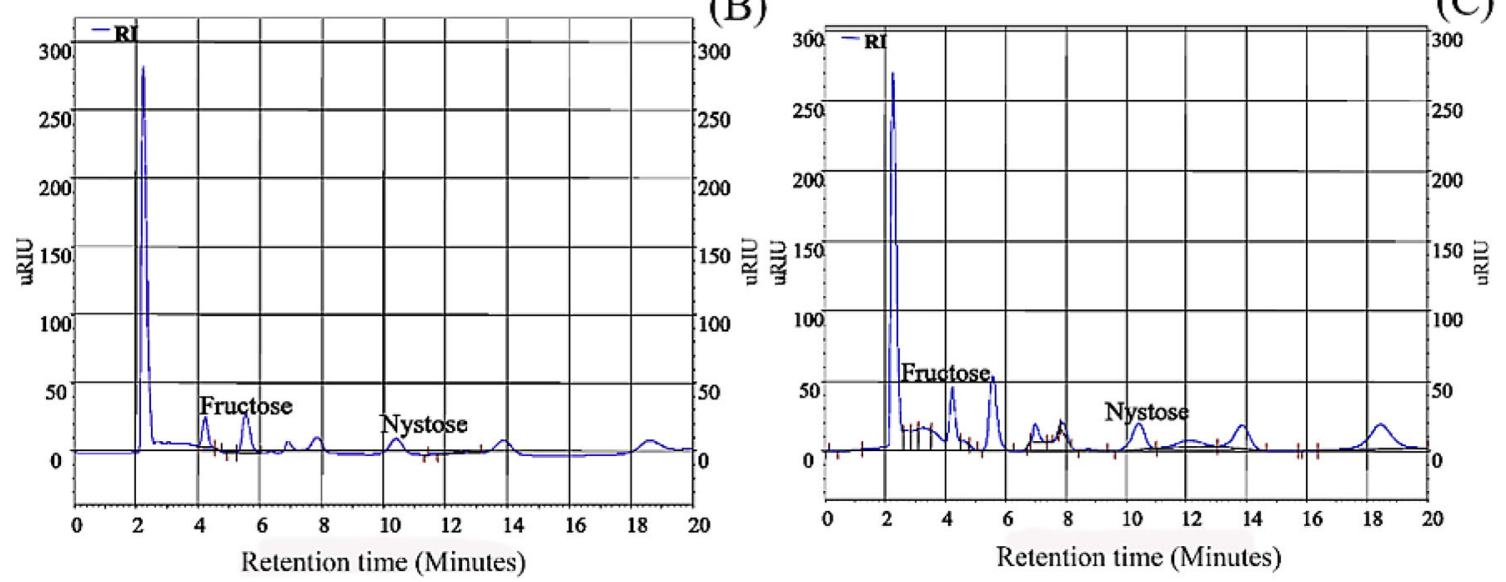

(D)
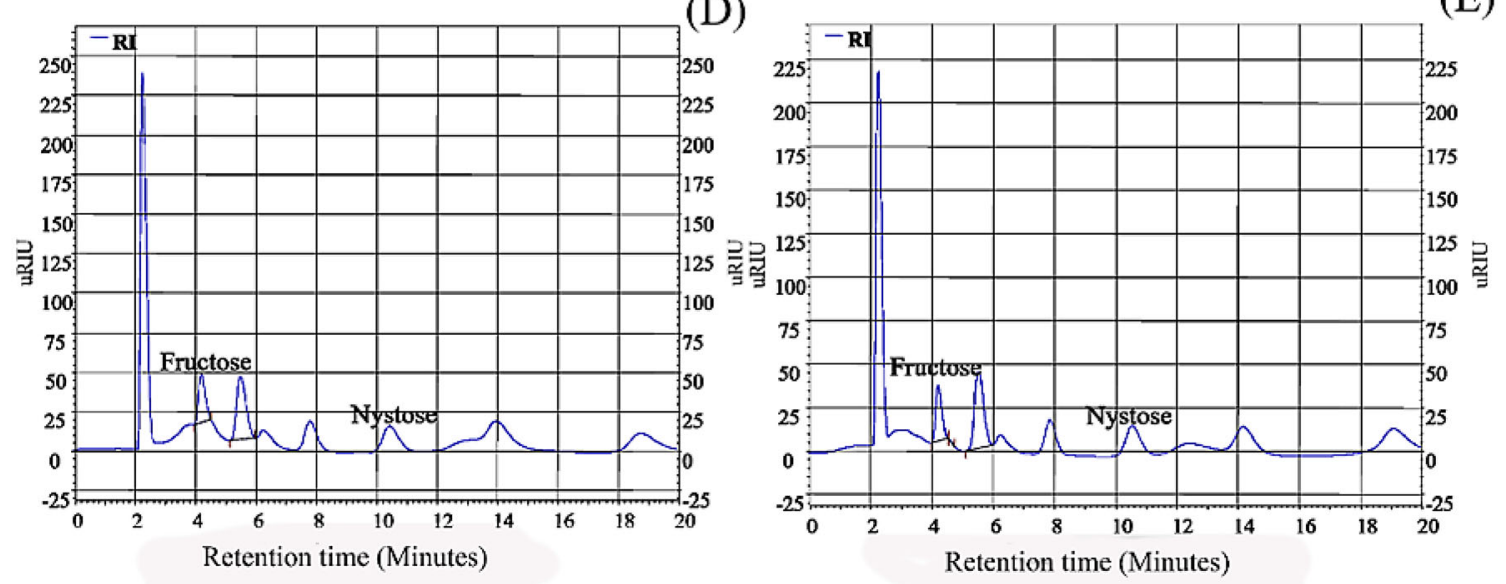

Fig. 4 Chromatogram of products formed in fructooligosaccharides obtainment by hydrolysis of inulin using A free inulinase, immobilized derivative using $\mathbf{B}$ eggshell by adsorption, $\mathbf{C}$ eggshell by covalent crosslinking, $\mathbf{D}$ Celite in aqueous medium, and $\mathbf{E}$ Celite in organic medium

Irrespectively of the enzyme formulation used, hydrolysis of inulin led to the production of fructose $(\mathrm{F})$ and nystose $\left(\mathrm{GF}_{3}\right)$, it given in Fig. 4. Production of 1-kestose was not observed.
The highest concentration of nystose $(9.49 \mathrm{~g} / \mathrm{L})$ was obtained with an inulin concentration of $250 \mathrm{~g} / \mathrm{L}(25 \%$, $\mathrm{w} / \mathrm{v}$ ) and a reaction time of $16 \mathrm{~h}$, corresponding to $3.87 \%$ of nystose yield. The response surface plot (Fig. 5A, B) shows the influence of the concentration of two 

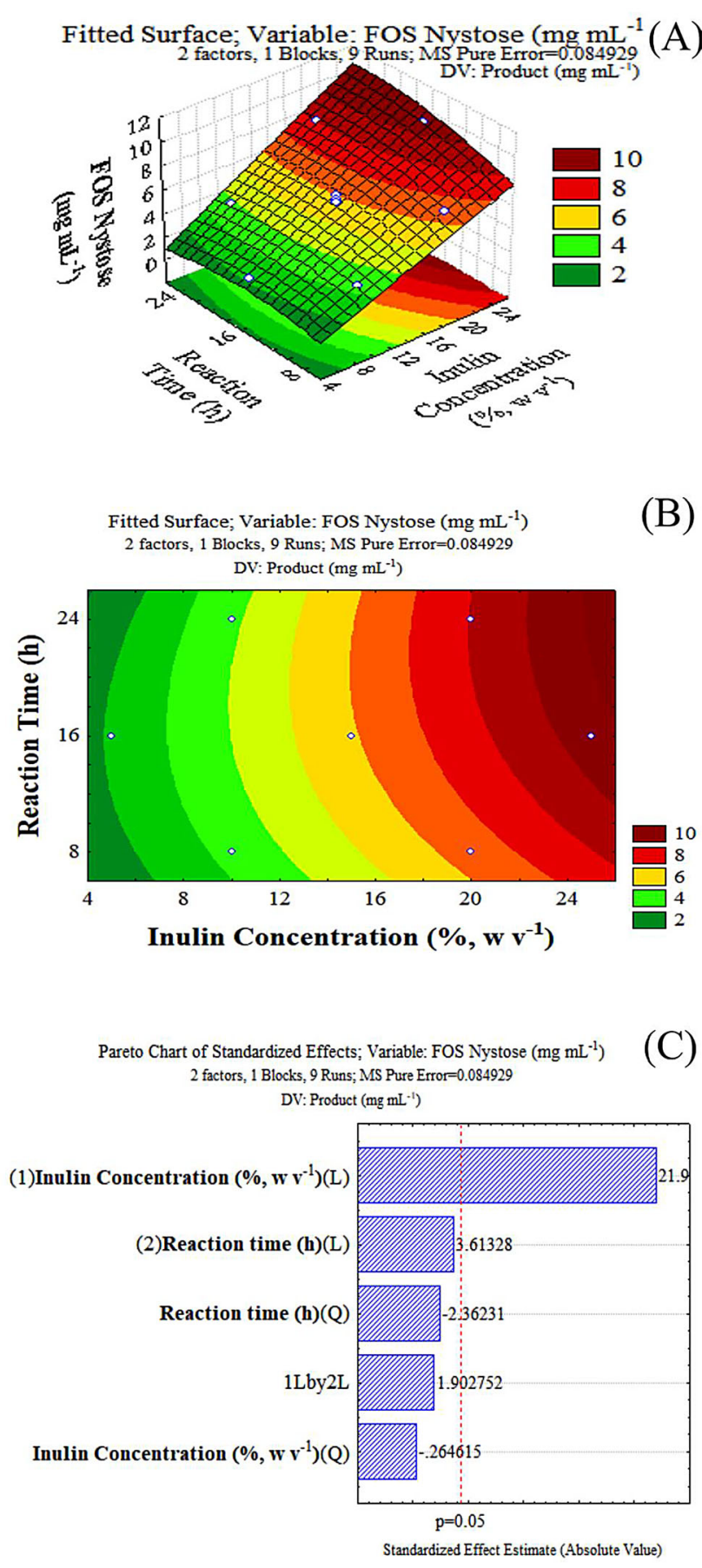

Fig. 5 A Response surface plot: optimization of the production of nystose through inulin hydrolysis using inulinase immobilized with Celite in aqueous medium by shifting inulin concentration and time of reaction; $\mathbf{B}$ area plot: optimization of the production of nystose; C Pareto plot: optimization of the production of nystose through inulin hydrolysis by shifting inulin concentration and time of reaction

independent variables, time and inulin, in nystose production. The Pareto plot (Fig. 5C) establishes that the initial concentration of inulin impacts the production of nystose while both the reaction time and the relationship between reaction time and the initial inulin concentration had no significant influence on nystose production at a $5 \%$ significance level.

The ANOVA found that for the optimization of FOS production, nystose had a calculated $\mathrm{F}$ value of 150.70 and an $\mathrm{R}^{2}$ of 0.99 . A regression model representative of the relationship between inulin concentration and duration of the reaction and concentration of nystose was developed (Eq. 6), where $\mathrm{A}$ is the response value (concentration of nystose), IC is inulin concentration, and DR is the duration of the reaction.

$$
\begin{aligned}
\mathrm{A}= & 1.08958+0.27959 \times(\mathrm{IC})-0.00070 \\
& \times(\mathrm{IC})^{2}+0.19751 \times(\mathrm{DR})-0.00736 \\
& \times(\mathrm{DR})^{2}+0.00693 \times(\mathrm{IC})(\mathrm{DR})
\end{aligned}
$$

The results obtained in the present work regarding FOS production from inulin hydrolysis are within the range reported in previous works. Chikkerur et al. (2020) produced FOS through enzymatic hydrolysis of inulin using partially purified endoinulinase secreted by A. fumigatus, with a maximum concentration of $4.33 \mathrm{~g} / \mathrm{L}$. Kuhn et al. (2013) produced FOS using A. niger inulinase immobilized on montmorillonite, with $3.44 \%$ of nystose yield in organic medium. Silva et al. (2013) used inulinase immobilized in sodium alginate (with and without treatment with pressurized $\mathrm{CO}_{2}$ ) for inulin hydrolysis to 1.6 and $4.85 \%$ nystose yield, respectively. Kuhn et al. (2016) relied on a commercial inulinase from $A$ niger immobilized on polyurethane foam and treated with pressurized liquefied petroleum gas (LPG) for the production of FOS and reported yields of $5.42 \%$ for 1 -kestose and $22.27 \%$ for nystose. These values are higher than the yield obtained in the present study, but they were obtained using sucrose rather than inulin as a substrate. Lower yields in FOS production when inulin rather than sucrose is used as substrate are probably related to the specificity of the enzyme and resistance to mass transfer (Kuhn et al., 2013).

Although several studies aimed to characterize microbial inulinases, few studies have reported the production of FOS by microbial inulinases produced by yeasts from the Bahian semiarid region, such as $R$. mucilaginosa. Most of the works described in the literature use microorganisms from Kluyveromyces, Aspergillus, Staphylococcus, Xanthomonas, and Pseudomonas as inulinase sources. Thus, inulinase production by other microorganism are interesting (Karboune et al., 2018; Picazo et al., 2018; Chikkerur et al., 2020). The production of FOS in organic solvent has several advantages compared to conventional aqueous systems, including changing the reaction balance towards synthesis instead of hydrolysis, reducing substrate and product inhibition, and variations in specificity of some enzymes (Karboune et al., 2018). 
The use of the yeast $R$. mucilaginosa (CCMB 604) in the production of inulinase proved to be a viable alternative for obtaining this enzyme since it presented activity similar to that obtained for filamentous fungi described in the literature, with the advantage of low cost and simple handling of the production process. Hence, such immobilized inulinase formulation can be foreseen as suitable candidates for application in industrial and biotechnological processes. The results of the application of inulinase from $R$. mucilaginosa in the production of FOS are encouraging. Since the supports used in immobilization have low cost and toxicity, the use of crude extract is appealing as it overcomes the relatively high cost and time required to purify the enzyme.

\section{Conclusion}

Doehlert experimental design allowed the identification of the optimal experimental conditions for both inulinase production and enzyme activity. Thus, inulinase production peaked for 12.5 and $0.5 \mathrm{~g} / \mathrm{L}$ concentrations of D-glucose and yeast extract; respectively, whereas the optimal $\mathrm{pH}$ and temperature for enzyme activity were 8.0 and $75{ }^{\circ} \mathrm{C}$, respectively.

The highest titer in fructooligosaccharides was obtained with an initial inulin concentration of $250 \mathrm{~g} / \mathrm{L}(25 \%$, w/v), and a reaction time of $16 \mathrm{~h}$. The highest concentration of nystose $(9.49 \mathrm{~g} / \mathrm{L})$ was obtained with an inulin concentration of $250 \mathrm{~g} / \mathrm{L}(25 \%, w / v)$ and a reaction time of $16 \mathrm{~h}$, corresponding to $3.87 \%$ of nystose yield. Enzyme immobilization using chicken eggshell and Celite supports proved efficient since enzyme activity was maintained and enabled FOS production from inulin hydrolysis. Hence, immobilized inulinase on either celite or eggshell proved to be promising catalysts for fructooligosaccharides production since the formulations were obtained through a simple, low-cost, and easily scalable methodology.

Acknowledgements This work was supported by FINEP (Financier of Studies and Projects), CAPES (Coordination of Improvement of Higher Level Personnel), CNPq (National Research Council), and FAPESB (Foundation for Research Support of the State of Bahia). We also thank the Biotechnology Graduate Program of the State University of Feira de Santana (UEFS/FIOCRUZ).

\section{Declarations}

Conflict of interest The authors declare that they have no conflict of interest.

\section{References}

Awad GEA, Wehaidy HR, Abd El Aty AA, Hassan ME. A novel alginate-CMC gel beads for efficient covalent inulinase immobilization. Colloid and Polymer Science. 295: 495-506 (2017)

Basso A, Serban S. Industrial applications of immobilized enzymesA review. Molecular Catalysis. 479: 110-607 (2019)

Bradford MM. A rapid and sensitive method for the quantitation of microgram quantities of protein utilizing the principle of proteindye binding. Analytical Biochemistry 72: 248-254 (1976)

Boudrant J, Woodley JM, Fernandez-Lafuente R. Parameters necessary to define an immobilized enzyme preparation. Process Biochemistry. 90: 66-80 (2019)

Castro HF, de Oliveira PC, Soares CMF, Zanin GM. Immobilization of porcine pancreatic lipase on celite for application in the synthesis of butyl butyrate in a nonaqueous system. Journal of the American Oil Chemists 'Society. 76: 147-152 (1999)

Chatterjee U, Kumar A, Sanwal GG. Goat liver catalase immobilized on various solid supports. Journal of Fermentation and Bioengineering. 70: 429-430 (1990)

Chi Z-M, Zhang T, Cao T-S, Liu X-Y, Cui W, Zhao C-H. Biotechnological potential of inulin for bioprocesses. Bioresource Technology. 102: 4295-4303 (2011)

Chikkerur J, Samanta AK, Kolte AP, Dhali A, Roy S. Production of Short Chain Fructo-oligosaccharides from Inulin of Chicory Root Using Fungal Endoinulinase. Applied Biochemistry and Biotechnology. 191: 695-715 (2020)

Dalla-Vecchia R, Nascimento M da G, Soldi V. Aplicações sintéticas de lipases imobilizadas em polímeros. Química Nova. 27: 623-630 (2004)

Datta S, Christena LR, Rajaram YRS. Enzyme immobilization: an overview on techniques and support materials. 3 Biotech. 3: 1-9 (2013)

Holyavka MG, Kayumov AR, Baydamshina DR, Koroleva VA, Trizna EY, Trushin M V., Artyukhov VG. Efficient fructose production from plant extracts by immobilized inulinases from Kluyveromyces marxianus and Helianthus tuberosus. International Journal of Biological Macromolecules. 115: 829-834 (2018)

Jain SC, Jain PC, Kango N. Production of inulinase from Kluyveromyces marxianus using Dahlia tuber extract. Brazilian Journal of Microbiology. 43: 62-69 (2012)

Jiang C, Cheng C, Hao M, Wang H, Wang Z, Shen C, Cheong LZ. Enhanced catalytic stability of lipase immobilized on oxidized and disulfide-rich eggshell membrane for esters hydrolysis and transesterification. International Journal of Biological Macromolecules. 105: 1328-1336 (2017)

Karboune S, Appanah N, Khodaei N, Tian F. Enzymatic synthesis of fructooligosaccharides from sucrose by endo-inulinase-catalyzed transfructosylation reaction in biphasic systems. Process Biochemistry. 69: 82-91 (2018)

Kuhn G de O, Rosa CD, Silva MF, Treichel H, de Oliveira D, Oliveira JV. Synthesis of Fructooligosaccharides from Aspergillus niger Commercial Inulinase Immobilized in Montmorillonite Pretreated in Pressurized Propane and LPG. Applied Biochemistry and Biotechnology. 169: 750-760 (2013)

Lima DM, Oliveira RQ, Uetanabaro APT, Góes-Neto A, Rosa CA, Assis SA. Thermostable inulinases secreted by yeast and yeastlike strains from the Brazilian semi-arid region. International Journal of Food Sciences and Nutrition. 60: 63-71 (2009)

Miller GL. Use of Dinitrosalicylic Acid Reagent for Determination of Reducing Sugar. Analytical Chemistry. 31:426-428 (1959)

Nascimento DS, Junior GV, Fernandes P, Ribeiro GCA, Lima DM, Góes-Neto A, Oliveira RQ, Figueiredo-Ribeiro R de CL, de Assis SA. Production, characterization and application of 
inulinase from fungal endophyte CCMB 328. Anais da Academia Brasileira de Ciências. 84: 443-453 (2012)

Nascimento DS, Lima DM, Junior GV, Oliveira R de Q, Fernandes P, Ribeiro R de CLF, Uetanabaro APT, GÃ3es-Neto A, Assis SA. Production, Characterization and Application of Inulinase from Pseudozyma sp. CCMB 300. Journal of Advances in Biotechnology. 4: 382-392 (2014)

Nguyen QD, Mattes F, Hoschke Á, Rezessy-Szabó J, Bhat MK. Production, purification and identification of fructooligosaccharides produced by $\beta$-fructofuranosidase from Aspergillus niger IMI 303386. Biotechnology Letters. 21: 183-186 (1999)

Nighojkar A, Srivastava S, Kumar A. Production of low methoxyl pectin using immobilized pectinesterase bioreactors. Journal of Fermentation and Bioengineering. 80: 346-349 (1995)

Oliveira LG, Cavalcanti MAQ, Fernandes MJS, Lima DMM. Diversity of filamentous fungi isolated from the soil in the semiarid area, Pernambuco, Brazil. Journal of Arid Environments. 95: 49-54 (2013)

Pace V, Sinisterra J V., Alcantara AR. Celite-Supported Reagents in Organic Synthesis: An Overview. Current Organic Chemistry. 14: 2384-2408 (2010)

Patching JW, Rose AH. The Effects and Control of Temperature. pp. 23-38. In: Methods in Microbiology. Norris JR, Ribbons D (ed). Academic Press, London, UK (1970)

Picazo B, Flores-Gallegos AC, Muñiz-Márquez DB, Flores-Maltos A, Michel-Michel MR, De La Rosa O, Rodríguez-Jasso RM, Rodríguez-Herrera R, Aguilar-González CN. Enzymes for fructooligosaccharides production: Achievements and opportunities. pp. 303-320. In: Enzymes in Food Biotechnology: Production, Applications, and Future Prospects. Kuddus M (ed). Academic Press, London, UK (2018)

Rawat HK, Ganaie MA, Kango N. Production of inulinase, fructosyltransferase and sucrase from fungi on low-value inulin-rich substrates and their use in generation of fructose and fructooligosaccharides. Antonie Van Leeuwenhoek. 107: 799-811 (2015)
Rawat HK, Soni H, Treichel H, Kango N. Biotechnological potential of microbial inulinases: Recent perspective. Critical Reviews in Food Science and Nutrition. 57: 3818-3829 (2017)

Ribeiro GC de A, Fernandes P, de Assis SA. Production, characterization, and immobilization of inulinase produced by Pseudozyma sp. (CCMB 306). Chemical Engineering Communications. 205: 1060-1068 (2018)

Salleh S, Serri NA, Hena S, Tajarudin HA. Preliminary studies on immobilization of lipase using chicken eggshell. IOP Conference Series: Earth and Environmental Science. 36: 0-6 (2016)

Sandoval-González SR, Jiménez-Islas H, Navarrete-Bolaños JL. Design of a fermentation process for agave fructooligosaccharides production using endo-inulinases produced in situ by Saccharomyces paradoxus. Carbohydrate Polymers. 198: 94-100 (2018)

Silva MF, Rigo D, Mossi V, Golunski S, De Oliveira Kuhn G, Di Luccio M, Dallago R, De Oliveira D, Oliveira JV, Treichel H. Enzymatic synthesis of fructooligosaccharides by inulinases from Aspergillus niger and Kluyveromyces marxianus NRRL Y-7571 in aqueous-organic medium. Food Chemistry. 138: 148-153 (2013)

Singh, RS, Singh T. Microbial inulinases and pullulanases in the food industry. pp. 23-52. In: Microbial Enzymes and Additives for the Food Industry. Sehrawat N (ed). Nova Science Publishers, Inc, New York, NY, USA (2019)

Trytek M, Fiedurek J, Podkościelna B, Gawdzik B, Skowronek M. An efficient method for the immobilization of inulinase using new types of polymers containing epoxy groups. Journal of Industrial Microbiology \& Biotechnology. 42: 985-996 (2015)

Publisher's Note Springer Nature remains neutral with regard to jurisdictional claims in published maps and institutional affiliations. 